\title{
The developmental origins of health and disease: current theories and epigenetic mechanisms
}

\author{
KD Sinclair ${ }^{1}$, RG Lea ${ }^{2}$, WD Rees ${ }^{3}$ and LE Young \\ 'School of Biosciences, University of Nottingham, Sutton Bonington, LE12 5RD, UK; 'School of \\ Veterinary Medicine, University of Nottingham, Sutton Bonington, LE12 5RD, UK; ${ }^{3}$ Rowetl Research \\ Institute, Bucksburn, Aberdeen, AB2t 9SB, UK; ${ }^{4}$ School of Human Development, University of \\ Nottingham, Nottingham, NG7 2UH, UK
}

The retrospective cohort studies of David Barker and colleagues during the late 1980 s established the principle that the incidence of certain adult diseases such as stroke, type 2 diabetes and dyslipidaemia may be linked to in utero development. Later termed the "Developmental Origins of Health and Disease (DOHaD)" hypothesis, there have been several more recent attempts to explain this phenomenon. Although a general conceptual framework has been established to explain how mechanisms may have evolved to facilitate rapid adaptations to changing ecological conditions, it doesn't identify the actual mechanisms responsible for such effects. Extensive covalent modifications to DNA and related proteins occur from the earliest stages of mammalian development. These determine lineage-specific patterns of gene expression and so represent the most plausible mechanisms by which environmental factors can influence development during the life course. In providing a contemporary overview of chromatin modifications during early mammalian development, this review highlights both the complexity and our current lack of understanding of how epigenetic alterations may contribute to in utero programming. It concludes by providing some thoughts to future research endeavours where the emphasis should be on bettering our understanding of epigenesis and devising more thoughtful experimental approaches that focus on specific environmental factors in appropriate animal and cellular models.

\section{Introduction}

Clinical interest in the concept that late onset diseases can originate from events occurring in utero arose from the initial retrospective cohort studies of Barker and Osmond (1988) and Barker et al. (1989), who assessed relationships between size at birth, hypertension and ischaemic heart disease in adult humans. Further studies established inverse relationships between birth weight and the incidence of stroke, type 2 diabetes and dyslipidaemia, and these phenomena, often collectively referred to as Syndrome X or metabolic syndrome, led to the "fetal origins (later to be called developmental origins) of health and disease" or "DOHaD" hypothesis (Barker 1995). However, the central tenet of this hypothesis, that low birth weight is associ- 
ated with elevated blood pressure or hypertension in adults, has since been challenged (e.g. Huxley et al. 2002). It transpires that reduced size at birth, which is only a proxy for suboptimal in utero conditions, is not necessarily associated with increased disease risk in adults. Nevertheless, the general consensus based on an overwhelming body of epidemiological evidence among different human populations and from direct-interventionalist studies with animals supports the general concept that sub-optimal in utero conditions can predispose to lateonset disease in adults (Langley-Evans 2006).

In the decade or so that followed the initial observations of Barker and colleagues a number of hypotheses were proposed to explain this phenomenon. Many attempted to support this hypothesis by setting it in a broader 'evolutionary' context. Numerous animal-based studies have also been conducted to determine the effects of exposure to specific environmental factors, at different stages of gestation, on indices of long-term health. The purpose of the present article is not to provide an exhaustive overview of this topic, which has been provided elsewhere (McMillen \& Robinson 2005), but rather to develop and critically assess some of the emerging concepts and related theories, whilst defining the role of heritable epigenetic modifications to DNA and associated proteins, Although studies in ruminants feature, the emphasis is on investigations which have provided unique conceptual insights into early mammalian development and some of the regulatory mechanisms where, in keeping with the original ideas of David Barker and colleagues, the bias is towards the effects of physiologically relevant alterations to maternal nutrition.

\section{DOHaD: Current controversies and related concepts}

Experimentally induced exposure to a number of environmental factors during in utero development is known to modify post-natal physiology. Although studies have been conducted in the mouse, guinea pig, and domesticated species such as the pig and horse, the favoured animal models to date have been the rat and sheep. Studies with these species have revealed that maternal insults during pregnancy can alter subsequent cardiovascular and metabolic function in offspring in the absence of effects on birth weight (Table 1). Indeed, these observations have contributed to the current debate as to whether or not birth weight per se has any causal effect on subsequent physiological function in offspring (Lucas et al. 1999). An emerging concept from this debate is that a period of accelerated or 'compensatory' growth, that frequently accompanies episodes of growth restriction, may underlie many of the adverse effects on cardiovascular function and metabolism observed during adulthood (Singhal \& Lucas 2004). Importantly, although initially proposed to defend the observation that catch-up growth during childhood in low-birth weight infants leads to cardiovascular disease (CVD) in adults, this hypothesis can be applied to any specific period during pre- and post-natal development.

\section{Thrifty phenotype and Predictive Adaptive Responses}

Much of the current thinking in the field (including that above) stems from the 'thrifty phenotype' hypothesis, originally proposed by Hales \& Barker (1992), which attempts to explain the link between fetal growth and the metabolic syndrome. This hypothesis proposes that poor nutrition in early life (particularly during fetal development) leads to permanent changes in glucose-insulin metabolism. Thus offspring malnourished during pregnancy or infancy are illequipped to cope with high calorie diets in later life. This concept has been expanded by some to consider such adaptations as a means by which phenotypic modifications can be induced within a single generation in order to best accommodate prevailing or anticipated 
Table 1. Examples of experimentally induced perturbations during pregnancy leading to altered physiology.

\begin{tabular}{|c|c|c|c|c|c|}
\hline \multirow[t]{2}{*}{ Intervention } & \multirow[t]{2}{*}{ Species } & \multirow{2}{*}{$\begin{array}{l}\text { Stage of } \\
\text { gestation }\end{array}$} & \multicolumn{2}{|c|}{ Physiological outcomes } & \multirow[b]{2}{*}{ Reference } \\
\hline & & & Pre-natal & Post-natal & \\
\hline \multicolumn{6}{|c|}{$\begin{array}{l}\text { A. Non-nutritional interventions } \\
\text { (i) With intra-uterine growth restric }\end{array}$} \\
\hline $\begin{array}{l}\text { Assisted reproduction } \\
\text { (e.g. IVF) }\end{array}$ & Mice & $<20 \%$ & $\begin{array}{l}\downarrow \text { fetal:placental } \\
\text { weight ratio }\end{array}$ & $\uparrow$ growth, $\uparrow$ adiposity & Sjöblom et al. (2005) \\
\hline Caranclectomy & Sheep & $14-20 \%$ & $\begin{array}{l}\text { Hypoxia, } \\
\text { hypoglycaemia }\end{array}$ & $\mathrm{N} / \mathrm{D}$ & Owens et al. (1989) \\
\hline $\begin{array}{l}\text { Maternal } \\
\text { hyperthermia }\end{array}$ & Sheep & $25-95 \%$ & $\begin{array}{l}\text { Hypoxia, } \\
\text { hypoglycaemia, } \\
\downarrow \text { ponderal index }\end{array}$ & $\uparrow$ neonatal mortality & Anthony et al. (2003) \\
\hline $\begin{array}{l}\text { Utero-placental } \\
\text { embolization }\end{array}$ & Sheep & $80-100 \%$ & $\uparrow$ mean arterial bp & $\downarrow$ mean arterial bp & Louey et al. (2000) \\
\hline $\begin{array}{l}\text { Glucocortiocoid } \\
\text { administration }\end{array}$ & Rat/Sheep & $67-100 \%$ & $\begin{array}{l}\uparrow \text { ventricular wall } \\
\text { thickness, - heart } \\
\text { rate and bp. }\end{array}$ & $\begin{array}{l}\uparrow \text { bp, hypertension, } \\
\text { hyperglycaemia, } \\
\text { hyperinsulinaemia }\end{array}$ & Seckle (2001) \\
\hline $\begin{array}{l}\text { Temporarily } \\
\text { induced anaemia }\end{array}$ & Sheep & $80-95 \%$ & $\begin{array}{l}\downarrow \text { haematocril, } \\
\downarrow \text { blood } 02\end{array}$ & $\begin{array}{l}\downarrow \text { adult weight, } \\
\uparrow \text { coronary conductan }\end{array}$ & $\begin{array}{l}\text { Davis et al. (2002) } \\
\text { ice }\end{array}$ \\
\hline $\begin{array}{l}\text { Between breed } \\
\text { embryo transfer }\end{array}$ & Horse & $0-100 \%$ & $\begin{array}{l}\uparrow \downarrow \text { in placental and } \\
\text { birth weights }\end{array}$ & $\begin{array}{l}\text { Cross dependent } \uparrow \\
\downarrow \text { arterial bp and } \\
\text { baroreflex sensitivity }\end{array}$ & Giussani et al. (2003) \\
\hline \multicolumn{6}{|c|}{$\begin{array}{l}\text { B. Nutritional interventions } \\
\text { (i) With intra-uterine growth re }\end{array}$} \\
\hline Low protein diet & Rat & $0-20 \%$ & $\begin{array}{l}\downarrow \text { blastomere } \\
\text { number }\end{array}$ & $\begin{array}{l}\uparrow \text { post-weaning } \\
\text { growth, systolic bp } \\
\text { (males) }\end{array}$ & Kwong et al. (2000) \\
\hline \multicolumn{6}{|c|}{ (ii) Without intra-uterine growth restriction } \\
\hline \multirow[t]{3}{*}{$\begin{array}{l}\text { Low prolein diet } \\
\text { ( } 9 \% \text { casein) }\end{array}$} & Rat & $0,33 \%$ & & $\begin{array}{l}\uparrow \text { weaning weight, } \\
\text { systolic bp (males) }\end{array}$ & $\begin{array}{l}\text { Langley-Evans et al. } \\
\text { (1996) }\end{array}$ \\
\hline & & $\begin{array}{l}34-67 \% \\
68-100 \%\end{array}$ & i birth weight & $\begin{array}{l}\uparrow \text { systolic bp } \\
\uparrow \text { weaning weight } \\
\text { (males), } \uparrow \text { systolic bp }\end{array}$ & \\
\hline & & $0-100 \%$ & & $\begin{array}{l}\uparrow \text { weaning weight } \\
\text { (males), } \uparrow \text { systolic bp }\end{array}$ & \\
\hline Lard enriched diet & Rats & $0-100 \%$ & $\mathrm{~N} / \mathrm{D}$ & $\begin{array}{l}\text { 个systolic, diastolic bp } \\
\text { (females) }\end{array}$ & Khan et al. (2003) \\
\hline \multirow[t]{4}{*}{$\begin{array}{l}\text { Global nutrient } \\
\text { restriction }\end{array}$} & Sheep & $-40-5 \%$ & $\begin{array}{l}\uparrow \text { arterial bp and } \\
\text { rate pressure } \\
\text { product in twins }\end{array}$ & $N / D$ & $\begin{array}{l}\text { Edwards \& McMllien } \\
(2002)\end{array}$ \\
\hline & Sheep & $0-20 \%$ & $N / D$ & $\begin{array}{l}\uparrow \text { pulse pressure, } \\
\downarrow \text { pulse pressure } \\
\text { product, blunted } \\
\text { baroreflex sensitivity } \\
\text { to Ang II }\end{array}$ & Gardner et al. (2004) \\
\hline & Sheep & $20-55 \%$ & $\mathrm{~N} / \mathrm{D}$ & $\begin{array}{l}\downarrow \text { nephron number, } \\
\uparrow \text { mean arterial bp }\end{array}$ & Gilbert et al. (2005) \\
\hline & Sheep & $70-80 \%$ & $N / D$ & $\begin{array}{l}\text { Altered hypothalamic- } \\
\text { piuitary-adrenal axis }\end{array}$ & $\begin{array}{l}\text { Bloomfield et al. } \\
(2003)\end{array}$ \\
\hline
\end{tabular}

$\uparrow, \downarrow=$ increase/decrease relative to Controls; $N / D=$ not determined; bp = blood pressure; Ang $I I=$ angiotensin II 
environmental circumstances (Bateson 2001; Gluckman \& Hanson 2004). Citing numerous examples within the animal kingdom, these authors distinguish such responses (termed Predictive Adaptive Responses [PARs]) from those that confer an immediate advantage or arise from disrupted or teratogenic development as a consequence of severe environmental challenges either during pregnancy or infancy. This hypothesis draws some support from long term followup studies of human populations subjected to famine during the second world war, for example, in The Netherlands during the winter of 1944-45 (Ravelli et al. 1998) and during the siege of Leningrad from 1941 to 1944 (Stanner et al. 1997); and from animal studies, including some of those listed in Table 1.

\section{Intergenerational transmission, Lamarckian inheritance and epigenetics}

An apparent limitation of the hypothesis proposed by Gluckman \& Hanson (2004) is that it is based on the premise that the in utero environment can provide the necessary cues for the fetus to predict future (i.e. post-natal) environmental conditions. Whilst it is understandable that appropriate in utero responses to circadian and seasonal cues may confer immediate post-natal advantages to the neonate, particularly for short-lived and altricial mammalian species, the longer term advantages, particularly for larger animals, are less apparent. Indeed, for longlived species, such as the human and ruminant, such responses would seem improbable, given that they have to transcend seasonal fluctuations in day length, climate and nutrient provision. Nevertheless, one population based study in humans conducted with subjects in both the northern and southern hemispheres demonstrated a clear effect of season of birth on longevity (autumn born babies live longer), which the authors (Doblhammer \& Vaupel 2001) attributed to in utero nutrition.

An attempt to explain the evolutionary significance of PARs was made by Kuzawa (2005), who considered the phenomenon in the context of life history theory. This is a branch of evolutionary biology which postulates that many physiological traits are linked to key maturational and reproductive characteristics that define the life course. Compelling evidence was presented that nutrient provision during pregnancy (particularly to the female fetus) conveys information reflecting the nutritional environments experienced by matrilineal ancestors. Termed 'Inter-generational Phenotypic Inertia' this hypothesis predicts that traits such as birth weight would have an inter-generational component; a prediction supported by data from the Dutch famine of 1944-1945 (Lumey 1992). However, such a mechanism is also expected to minimise the influence of immediate or short-term fluctuations in nutrient provision, typically associated with seasonal or other stochastic factors, in favour of longer-term strategic goals reflecting changing ecological conditions. That is, according to this model, the effects of PARs within a single generation would be minimal, but would accumulate across generations. Furthermore, the hypothesis predicts (and some evidence is presented) that the 'buffering effect' afforded by this mechanism primarily benefits the female fetus, so that the male fetus may be more susceptible to factors experienced by the mother during pregnancy (Kuzawa 2005). Indeed, in a nutritional re-alignment study with rats which had been offered a low protein diet for 12 generations the following observations were made during nutritional realignment: (i) there was a graded response in terms of increased birth weight and cognitive abilities which depended on the timing of protein re-alignment (in utero $>$ from birth $>$ from 4 weeks), and (ii) further incremental improvements in residual physical and behavioural outcomes were observed over the following two generations (Stewart et al. 1980). Importantly, the effects of both the initial 12 generations of protein restriction and of dietary re-alignment were greater in male offspring. The full significance of this gender-effect specifically in the context of DOHaD, however, 
remains to be confirmed. The available evidence is inconclusive as unfortunately few experiments have considered long-term intergenerational effects, and experiments have often been conducted with insufficient power to determine gender effects within a single generation.

Nevertheless, such phenomena evoke the ideas of the French naturalist Jean-Baptiste Lamark (1744-1829), who proposed that the inheritance of acquired characteristics is the hereditary mechanism by which changes in physiology acquired during the lifetime of an organism are transmitted to its offspring. Previously refuted in favour of Darwin's theories on natural selection, the emerging field of epigenetics, whilst in no way contradicting the laws of natural selection, has provided a potential mechanism for Larmark's ideas on the inheritance of acquired traits. The environmental lability of acquired epigenetic modifications, particularly during the earliest stages of development (discussed later), provides a mechanistic basis for predictive adaptive responses and transgenerational inheritance.

\section{Effects on fertility}

Investigations into the long-term consequences of the war-time famine in The Netherlands revealed that undernutrition during gestation can lead to a number of disease states in later life, the nature and severity of which are dependent on the stage of gestation at the time of insult (Painter et al. 2005). A striking observation from studies with this cohort, however, was that the subsequent fertility of offspring undernourished during pregnancy was unaffected (Lumey 1998). Although there are reported effects on ovulation rate among non-obese adolescent girls born small for gestational age (effects associated with central adiposity and dyslipidaemia (Ibáñez et al. 2002), it remains to be seen if these effects persist to normal reproductive age. Furthermore, whilst it is clear that ovulation rate and/or litter size in adult ewes can be reduced by undernutrition during fetal development (Rae et al. 2002) or during the pre-pubertal period (Rhind et al. 1998), there seems to be little effect on male fertility and no effect on the incidence of barreness among ewes; that is, it seems that fertility is not affected.

These observations are consistent with current theories on PARs and the transgenerational effects discussed earlier. Teleologically, it makes sense that a polyovular species, faced with a long-term decline in nutrient provision, would attempt to reduce ovulation rate. Failure to ovulate, which impedes the initiation of pregnancy, could only be an emergency measure of short-term significance, unsustainable in the longer term. It would also seem probable for longlived species faced with several generations of nutritional impoverishment that, in addition to a reduction in mature size (Kuzawa 2005), puberty would be delayed and reproductive senescence advanced. Although there is a considerable body of evidence to support a delay in the onset of puberty under such circumstances in humans (Frisch 1994), at present there is limited evidence to support the notion that growth restriction during late gestation or during early childhood advances the onset of menopause (Cresswell et al. 1997; Hardy \& Kuh 2002). Regrettably, this is an area where there appears to be a dearth of suitable animal models (Roof et al. 2005; Danilovich \& Ram Sairam 2006). Given the evolutionary theories concerning ageing discussed next it would seem that rodents are not best suited for the study of reproductive senescence in humans.

\section{Evolutionary theories of ageing}

Many of the existing evolutionary theories on ageing intricately link fecundity to mature size and lifespan, and so go some way to underpin many of the current hypoptheses on the origins of adult health and disease (Holliday 2005). The 'accumulated mutations' theory first proposed 
by PB Medawar in 1952, for example, proposes that deleterious genetic mutations that are manifest at a young age would be selected against whereas those displayed in late (postreproductive) life would not, and so would accumulate across generations. A related theory, the 'antagonistic pleiotropy' theory (proposed GC Williams in 1957), suggests that genes exist which confer an advantage early in life (e.g. increased fecundity or cancer resistance) but which later advance the onset of age-related senescence. To date, however, this has been mainly supported from studies with the fruit fly and nematode with only limited evidence from the mouse (Leroi et al. 2005). More recently a third theory has attracted greater interest. The 'disposable soma' theory links the energy costs of maintenance to extrinsic mortality (e.g. predation), fecundity and longevity (Kirkwood 2005). The theory considers trade-offs between maintenance and reproduction, so that small mammals that develop and reproduce early, and have larger litters, have shorter lifespans. In contrast, in the absence of factors contributing significantly to extrinsic mortality, natural selection favours species that are better adapted to their environment, so that mature size increases, reproductive rates are reduced, reproduction occurs later and longevity is increased. This theory explains the rather paradoxical scenario where caloric restriction throughout life enhances longevity; a feat achieved through reductions in fecundity. The effect in rodents (a species utlised extensively in investigations into the DOHaD hypothesis) has been estimated to be 10 times greater than that in humans (Phelan \& Rose 2005); demonstrating the extent to which these small mammals invest in reproduction (or annual fecundity rate), also calculated to be 10 times greater in rodents than in humans.

In pursuit of immortality: the germline and the soma

Primordial germ cells (PGCs) in mammals are derived from the inner-cell mass and are segregated from the somatic lineage during the early stages of gastrulation (Matsui \& Okamura 2005). Destined to differentiate into gametes, these specialised cells are unique in that they give rise to the lineage responsible for the transfer of the genome from one generation to another. Relieved from the responsibility of transgenerational inheritance at an early stage in metazoan evolution, the surrounding soma was able to specialise into the many other cell types found in multicellular organisms but, in so doing, these cells incurred a cost; that is they became expendable. In his 'deprivation syndrome paradigm', Heininger (2002) explained that during early metazoan evolution a common strategy in response to environmental stress was to redirect resources from the soma towards the germline (e.g. the dying fruiting body and germlike spores of Dictyostelium). Ageing, it was argued, evolved as a counter measure on the part of the soma to postpone its inevitable demise.

It follows that the distinction between the germ line and the surrounding soma in higher organisms, and the conflict that exists between them, is central to the current thinking on the evolution of ageing and age-related disease, under-pinning the ideas presented earlier about the trade-off between somatic maintenance and reproductive effort in a world of finite resources (Kirkwood 2005). This evolutionary conflict led Heininger (2002) to state that "death is no altruistic suicide but is imposed on the soma by the "enemy within", the germ cells".

\section{The case for DOHaD}

Some of the hypotheses described in this section predict that, at least in viviparous species, environmental influences from the earliest stages of development can alter key physiological processes during the life course. Some of these modifications may be adaptive responses, some may not, but all could contribute either directly or indirectly to DOHaD. Set in the 
context of life history theory, the hypothesis of 'trans-generational phenotypic inertia' further predicts that these effects accumulate gradually over successive generations. The 'disposable soma' theory links reproductive effort to extrinsic mortality and resistance to 'environmental stress', and forms the basis of the concept that ageing, and age-related diseases, are an inevitable consequence of the efforts of the soma to evade death; which in an evolutionary context is seen as a 'germ-cell triggered' event.

The importance of understanding these latter hypotheses are two-fold. Firstly, it may yet transpire that germ cells are uniquely resistant to in utero 'programming' effects, which have so clearly been demonstrated in somatic lineages; so that traits such as fertility may be unaffected by factors such as maternal nutrition during pregnancy. In this regard, the onset of reproductive senescence will be an important future area of study. Secondly, as many of the post-natal health-related outcomes programmed in utero are displayed during 'post-reproductive' life, so they may be intricately linked to the mechanisms that extend life; that is, these mechanisms may also be 'programmed' in utero.

Although compelling, evidence supporting many of these hypotheses is largely correlative and the mechanistic basis for the observed effects remains to firmly established. The period of in utero development, however, would appear to be particularly sensitive to alterations in the maternal environment. This is perhaps not surprising given that, of the estimated 43 cell divisions that occur during the course of human development, 37 have been predicted to take place in utero (Freitas 1999), with 8 occurring during the pre-implantation period. It follows that as each round of cell division is accompanied by a round of DNA replication, so the mechanistic basis for in utero programming of adult health and disease may reside in subtle alterations to ongoing chromatin or epigenetic modifications taking place during the normal processes of cellular differentiation and lineage commitment.

\section{Epigenetics: the chemical basis for change}

The modern use of the term epigenetics is to describe heritable changes in gene function that occur without an alteration in DNA sequence. These changes arise principally as a consequence of specific covalent modifications to DNA and associated histone proteins which act in concert with chromatin structure to define the transcriptome associated with a specific cell lineage. Epigenetic inheritance is therefore defined as the transmission of such modifications from a cell (or multicellular organism) to its descendants without any alteration in nucleotide sequence.

\section{Histone modifications}

The nucleosome is the functional unit of chromatin and consists of an octomeric complex of core histone proteins $(\mathrm{H} 2 \mathrm{~A}, \mathrm{H} 2 \mathrm{~B}, \mathrm{H} 3$ and $\mathrm{H} 4)$, around which is wrapped 146 bp of DNA. A single histone $\mathrm{H} 1$ polypeptide interacts with an additional $20 \mathrm{bp}$ of DNA as it enters and leaves the nucleosomal core. The negatively charged DNA is usually very tightly associated with the positively charged $\mathrm{N}$-terminal histone tails which protrude from the core. Specific amino acid residues on these tails are targets for a number of enzyme-catalysed post-translation modifications which affect their charge and function (Table 2). This, in turn, can affect the configuration of the chromatin resulting in either a tightly bound heterochromatic configuration or a more open euchromatic configuration. These modifications can also serve to direct the binding of transcription factors and DNA damage repair proteins. 
Table 2. Examples of post-translational histone modifications in mammalian cells.

\begin{tabular}{|c|c|c|c|c|c|c|}
\hline $\begin{array}{l}\text { Histone } \\
\text { modification }\end{array}$ & $\begin{array}{l}\text { Histone and } \\
\text { residue }\end{array}$ & $\begin{array}{l}\text { Modifying } \\
\text { enzyme }\end{array}$ & $\begin{array}{l}\text { Demodifying } \\
\text { enzyme }\end{array}$ & Function & Species & Reference \\
\hline \multirow[t]{2}{*}{ Acètylation } & $\mathrm{H} 3 \mathrm{~K} 14$ & GCN5/PCAF & HDACT & $\begin{array}{c}\text { Transcriptional } \\
\text { activation }\end{array}$ & $\mathrm{Hn}$ & Yamagoe et al. (2003) \\
\hline & $\mathrm{H} 4 \mathrm{~K}$ ? & HAT 1/GCN 5 & HDAC $1,2,3,7$ & $\begin{array}{l}7 \text { Activation/ } \\
\text { Repression }\end{array}$ & Bov. & McGraw et al. (2003) \\
\hline \multirow[t]{3}{*}{ Phosphorylation } & on H3S10 & Aurora-B-Kinase & $?$ & $\begin{array}{c}\text { Transcriptional } \\
\text { activation }\end{array}$ & Ms & Fischle et al. (2005) \\
\hline & $\mathrm{H} 3 \mathrm{~T} 11$ & DIk/ZIP Kinase & $?$ & Mitosis & $\mathrm{Hn} / \mathrm{rat}$ & Preuss et al. (2003) \\
\hline & $\mathrm{H} 2 \mathrm{AX}$ & PI3 Kinase & PP2A & DNA damage repair & ir $\mathrm{Hn}$ & $\begin{array}{l}\text { Chowdhury et al. } \\
\text { (2005) }\end{array}$ \\
\hline \multirow[t]{4}{*}{ Methylation } & $\mathrm{H} 3 \mathrm{~K} 4$ & Set9 & LSD1 & $\begin{array}{c}\text { Transcriptional } \\
\text { activation }\end{array}$ & $\mathrm{Ms} / \mathrm{Hn}$ & $\begin{array}{l}\text { Francis et al. (2005) } \\
\text { Shi et al. (2004) }\end{array}$ \\
\hline & $\mathrm{H} 3 \mathrm{Kg}$ & SUV $39 \mathrm{HI}$ & c & $\begin{array}{l}\text { DNA methylation/ } \\
\text { heterochromalin }\end{array}$ & $\mathrm{Hn}$ & Snowden et al. (2002) \\
\hline & $\mathrm{H} 3 \mathrm{R} 17$ & CARMI & PAD4 & $\begin{array}{c}\text { Transcriptional } \\
\text { activation }\end{array}$ & $\mathrm{Hn}$ & Wang et al. (2004) \\
\hline & $\mathrm{H} 4 \mathrm{R} 3$ & PRMTI & PAD4 & $\begin{array}{l}\text { Transcriptional } \\
\text { activation }\end{array}$ & $\mathrm{Hn}$ & Wang et al. (2004) \\
\hline Ubiquitylation & H2AK 199 & Ring $1 b$ & $?$ & $\begin{array}{l}\text { X-inactivation } \\
\text { in trophoblast }\end{array}$ & Ms & Fang et al. (2004) \\
\hline Sumoylation & $\mathrm{H} 4$ & UBC9 & $\begin{array}{r}\text { ULP proteases? } \\
\text { Vi. }\end{array}$ & $\begin{array}{l}\text { s? Repression } \\
\text { via } H D A C \text { and } H P 1\end{array}$ & $\mathrm{Hn}$ & $\begin{array}{l}\text { Shiio \& Eisenman } \\
\text { (2003) }\end{array}$ \\
\hline
\end{tabular}

Histone $(\mathrm{H})$; lysine $(\mathrm{K})$; arginine $(\mathrm{R})$; serine $(\mathrm{S})$; threonine $(\mathrm{T})$; human $(\mathrm{Hn})$; mouse (M) ; bovine (Bov)

The post-translational modifications that occur to these histone proteins have been best studied in yeast ( $S$. cerevisiae and S. pombe), the fruit fly (D. melanogaster) and in Arabidopsis (Bannister \& Kouzarides 2005). Of these modifications histone acetylation is perhaps the best understood. This modification involves acetyl substitution of the $\varepsilon$-amino group of lysine $(K)$ (e.g. $\mathrm{H} 3 \mathrm{~K} 9$ or $\mathrm{H} 4 \mathrm{~K} 12$ ) which results in a more acidic (less positive) state. These reactions are catalysed by members of one of five families of histone acetyltransferases (HATs) (Kouzarides 1999); the reverse reactions being catalysed by histone deacetylase (HDAC) of which there are are 17 known mammalian members belonging to three classes.

Histone methylation occurs on non-acetylated lysine and arginine residues, and the methylation of $\mathrm{H} 3$ and $\mathrm{H} 4$ has attracted most attention where the outcomes can either be stimulatory or inhibitory depending on the particular lysine and arginine residue modified. Methylation of lysine and arginine residues is directed by histone methyltransferase (HMT) and protein arginine methyltransferase (PRMT) family members respectively; the former can direct Sadenosylmethionine (SAM) mediated methylation of lysine residues (Lee et al. 2005). In contrast to histone methyltransferases, the identification of histone demethylases is comparatively recent, and so our understanding of how these enzymes operate is incomplete (Bannister \& Kouzarides 2005). A key feature of these post-translational modifications, however, is that they seldom act in unison but there exists considerable 'cross-talk' between these processes (Fischle et al. 2003). What's more, these histone modifications are intricately linked to covalent DNA modifications to collectively define the transcriptome. Details of such interactions are only now emerging but they highlight a complex bi-directional interplay, for example, between histone acetylation, methylation and DNA methylation (Fuks 2005). 
DNA methylation

DNA methylation involves the addition of a methyl group to the number 5 carbon atom of the cytosine pyrimidine ring. This covalent modification is targeted to $\mathrm{CpG}$ dinucleotides which are recognised by DNA methyltransferase enzymes (DNMTs) (Goll \& Bestor 2005). It has been estimated that around $75 \%$ of CpG dinucleotides in the human genome are methylated and are to be found in non-translated and heterochromatic regions; the remaining $25 \%$ unmethylated sites being located in specific 1 to $2 \mathrm{~kb}$ regions known as CpG islands (Caiafa \& Zampieri 2005). These CpG islands, in turn, are frequently found in the promoter regions of genes. Among its numerous roles, DNA methylation is thought to serve in tissue-specific gene expression, X-chromosome inactivation, genomic imprinting and the silencing of transposable elements which constitute around $45 \%$ of the human genome (Lander et al. 2001). A key feature of DNA methylation, currently thought to distinguish it from many other chromatin modifications, is that it is normally faithfully restored during each cell cycle so that methylation patterns established during the earliest stages of development can persist in adult somatic cells. At present, the temporal means by which DNA methylation is targeted to specific regions of the genome is poorly understood, although it is thought to involve protein-protein interactions between the DNMTs and transcriptional repressor proteins, chromatin insulators and RNA-mediated interference (Klenova et al. 2002; Klose \& Bird 2006). Methylated DNA in turn attracts methyl-CpG-binding proteins and these interact with other repressor proteins, including HDACs, to form transcriptional repressor complexes.

Although DNA methylation is thought to be an irreversible reaction, catalysed exclusively by members of the DNMT family of methyltransferases, it has long been recognised that active-demethylation of paternally-derived single copy genes takes place in the mammalian zygote (Oswald et al. 2000); and there is emerging, albeit controversial, evidence that DNA methylation in other cell types may also be fashioned by demethylase activity (Santos et al. 2002; Vairapandi 2004). The universal methyl donor SAM has been shown to inhibit demethylase activity (Detich et al, 2003), and so intracellular depletion of SAM may lead to a reduction in DNA methylation by reducing the provision of labile methyl groups and by increasing DNA demethylase activity.

\section{Methyl cycle metabolism}

The metabolic cycles which supply methyl groups for DNA and histone methylation involve a complex series of interactions between a number of different intracellular metabolites (Stipanuk 2004) (Fig. 1). The two principal methyl donors in animal metabolism are betaine (trimethyl glycine), a metabolite of choline, and SAM, a metabolite of methionine. SAM is a universal donor of methyl groups providing one-carbon moieties for phospholipid biosynthesis, creatine production and protein synthesis in addition to DNA methylation. In donating its methyl group to an acceptor, SAM is converted to S-adenosyl homocysteine (SAH). The subsequent loss of the adenosine residue produces the non-protein amino acid homocysteine (hcy), a central intermediate in the metabolism of sulphur in all animals. Homocysteine in turn can either be catabolised to cystathionine in the trans-sulphuration pathway or remethylated to form methionine. In mammals, two separate enzymes catalyse the remethylation step to complete a cycle which enables other molecules, notably serine and glycine, to act as methyl donors. One enzyme (methionine synthase, MTR) utilises a derivative of folic acid, N5methyltetrahydrofolate as the methyl donor. The reaction is mediated by the coenzyme, methylcobalamin, derived from dietary vitamin B12 (cyanocobalamin). The activity of this 
reaction is therefore determined by the availability of two B vitamins, namely folic acid and cyanocobalamin. An alternative re-methylation reaction using betaine as the cofactor is also available to convert hcy to methionine. As betaine is derived from the breakdown of choline, the activity of this enzyme (betaine-hyc methyl transferase; BHMT) is partly determined by the availability of choline in the diet.

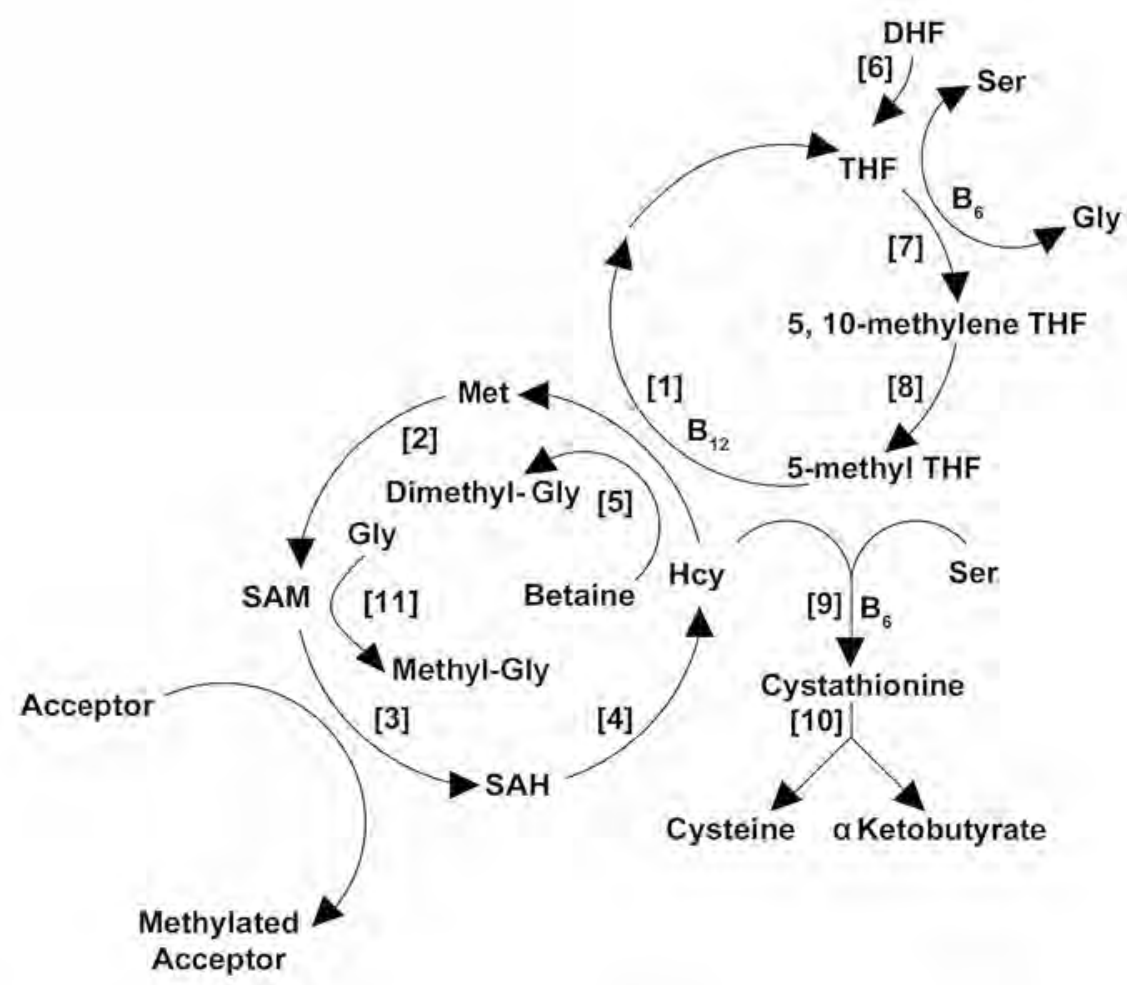

Fig. 1. Combined methionine and folate cycles. Metabolites: Methionine (Met), S-adenosyl methionine (SAM), S-adenosyl homocysteine $(\mathrm{SAH})$, homocysteine $(\mathrm{Hcy})$, dihydrofolate (DHF), tetrahydrofolate (THF), serine (Ser), glycine (Gly), methylcobalamin (B12), pyridoxal phosphate (B6). Enzymes: methionine synthase [1], methionine adenosyl trasnferase [2], SAM-dependent methyltransferases [3], SAH-hydrolase [4], betaine-homocysteine methyltransferase [5], dihydrofolate reductase [6], serine hydroxymethyl transferase [7], 5,10-methylene THF reductase [8], cystathionine b-synthase [9], cystathionine g-lyase [10], glycine methyltransferase [11].

In contrast to rats, the total capacity of choline oxidase and BHMT is much lower than MTR in the adult sheep (Table 3). This reflects differences in the metabolism of the two species. Adult ruminants derive only a limited quantity of the precursors of transmethylation from the diet as those that are present are degraded by rumen microbial action. The transition from pre- (neonatal) to post-ruminant states in ruminants results in a decline in choline and creatine availability leading to a modification in single carbon metabolism. Nevertheless, both human subjects and sheep exhibit strikingly similar rates of methionine recycling, despite differences in dietary methyl group provision (Lobley et al. 1996). 
Table 3. Methyl cycle enzyme activity (adapted from Snoswell \& Xue, 1987)

\begin{tabular}{|c|c|c|}
\hline \multirow[t]{2}{*}{ Enzyme } & \multicolumn{2}{|c|}{$\begin{array}{c}\text { Specific activity } \\
\text { (pmol/min/mg prolein) }\end{array}$} \\
\hline & Sheep & Rats \\
\hline Choline oxidase & 294 & 7980 \\
\hline Betaine Hcy methyt transferase & 130 & 725 \\
\hline Methionine symthase & 203 & 55 \\
\hline Glycine methyltransferase & 25 & 7098 \\
\hline
\end{tabular}

Metabolic responses to methyl nutrients are also known to differ between individuals as a result of polymorphic variation in at least four enzymes involved in these cycles. For example, the $677 \mathrm{C}$ to T polymorphism in methylene tetrahydrofolate reductase (MTHFR) reduces enzyme activity and is highly prevalent among Caucasians (5-15\% for the $\Pi T$ and $40-50 \%$ for the CT genotypes respectively). Such individuals require high intakes of folic acid to reduce plasma hcy concentrations (de Bree et al. 2003). Given the central role of MTR in ruminant single-carbon metabolism, it is interesting to note that the A to $\mathrm{G}$ polymorphism at position 2756 of this gene is common in human subjects ( 40\% and 5\% for AG and GG genotypes respectively; Sharp \& Little 2004).

\section{Epigenetic programming during development}

Given that the genetic code does not vary between cell types, the transition to multicellularity and the division between the germline and the soma necessitated the evolution of epigenetic mechanisms (such as the methylation of DNA) that would determine lineage-specific gene expression (Jablonka 1994). Recent studies using restriction landmark genome-scanning (RLGS) have identified numerous tissue-specific differentially methylated regions (DMRs) within CpG islands in both germ and somatic cells of differing lineages in mice (Shiota et al. 2002; Kremenskoy et al. 2003). The temporal complexity of the epigenetic mechanisms that direct somatic cell lineage specification was further illustrated by Rupp et al. (2002) who considered the interactions that exist between myogenic regulatory proteins and chromatin modifying enzymes during the differentiation of skeletal muscle. Both MyoD and Myf5 are expressed during somitic myogenesis under the influence of Sonic hedgehog and Wnt-1, and serve to induce mesodermal precursor cells to differentiate into myoblasts, as well as activating downstream target genes such as myogenin (Maltin et al. 2001). MyoD expression is associated with a loss of methylation at a conserved distal enhancer element known to mediate its activation. The DNA binding activity of MyoD is regulated by both HATs and HDAC and, together with Myf5, MyoD is believed to initiate target gene transcription by recruiting mammalian SW1/SNF complexes (members of the trithorax group of proteins associated with euchromatin). It is interesting, therefore, that temporal shifts in Myf5 protein expression in proliferating ovine fetal muscle cells should be induced by temporarily exposing Day 3 pre-implantation embryos to an advanced uterine environment (Maxfield et al. 1998); suggesting that events occurring during the earliest stages of post-fertilisation development can alter down-stream gene expression and cellular proliferation (discussed later).

Epigenetic mechanisms are also known to participate in the specification and formation of primordial germ cells. (Allegrucci et al. 2005a). Crucially, these cells undergo additional dramatic epigenetic modifications during gametogenesis that serve to erase epimutations, reestablish totipotency and establish sex specific imprints. Yet further important modifications 
occur following fertilisation in the period leading up to zygotic gene activation; modifications which may herald the initiation of the genetic conflict that is thought to exist between the sexes (Moore \& Reik 1996) and/or that are associated with zygotic activation and preparation for implantation.

\section{Epigenetic modifications following fertilisation}

Epigenetic programming during pre-implantation development has been extensively studied in the mouse, where the paternally derived genome is actively (in the absence of DNA replication) demethylated during the first cell cycle, consistent with early male pronuclear and zygotic gene transcription in this species (Schultz, 2002). Recent studies using immunoflourescent staining targeted to heterochromatic regions in one-cell mouse embryos have revealed that, as the sperm nucleus decondenses, it acquires $\mathrm{H} 3-\mathrm{K} 9$ acetylated and monomethylated histones as the DNA becomes progressively demethylated (Santos et al. 2005). In contrast, the maternal pronucleus retains high levels of $\mathrm{H} 3$ di- and tri-methylated $\mathrm{K} 9$ and $\mathrm{K} 27$, which these authors suggest may serve to protect DNA methylation in the maternal genome at this time.

Whilst similar patterns of global DNA demethylation of the paternal genome have been observed in the rat, cow and human zygote, there are significant differences in the rabbit and sheep zygote (Beaujean etal. 2004a). Through the use of interspecies intracytoplasmic sperm injection, these authors were able to demonstrate that the more extreme loss of paternal demethylation in the mouse compared to the sheep male pronucleus arises as a consequence of (1) the enhanced resistance of sheep sperm to demethylation and (2) the greater demethylating capacity of the mouse ooplasm (Beaujean et al. 2004b). Subsequent cell divisions during the early pre-implantation period are associated with further losses of DNA methylation which again are more extreme in the mouse than either the cow or sheep genomes (Beaujean et al. 2004a). Although the functional significance of these species-related differences in DNA methylation are unclear, they may partly be due to pre-existing levels of methylation in the male pronucleus at the time of syngamy, or to differences in the timing of embryonic gene activation (discussed by Young \& Beaujean, 2004). There are also species differences in the expression patterns of DNMTs in oocytes and pre-implantation embryos (Golding \& Westhusin 2003; Vassena et al. 2005) which could partially account for these effects.

\section{Epigenetic modifications in germ cells}

Primordial germ cells in mammals are believed to be specified from the epiblast during the early stages of grastrulation. Most extensively studied in the mouse, their specification has been found to involve complex interactions between maternally inherited and zygotically induced molecules in a multi-step process (Matsui \& Okamura 2005). In addition to epigenetic modifications associated with germline specification during this period, PGCs undergo further unique epigenetic alterations believed to coincide with their migration across the genital ridge (reviewed by Allegrucci et al. 2005a). From around 10.5 days post coitum in the mouse, single copy imprinted and non-imprinted genes are actively demethylated, thereby ensuring that epigenetic modifications that accumulate in somatic cells with age are erased through the germline. In contrast, the demethylation of repetitive elements is more protracted, variable and generally less complete; a process hypothesised to be a protective mechanism designed to minimise transposition and aberrant expression of adjacent genes (Hajkova et al. 2002). 
Sex-specific remethylation of PGCs then takes place in the gonad. However, the timing of de novo methylation differs between the male and female germlines, at least in the mouse. Remethylation in the male, and the re-establishment of gametic imprints, commences in mitotically dividing (pre-meiotic) spermatogonial stem cells (Rousseaux et al. 2005). In contrast, the timing of de novo methylation in the female germ cell is less certain, but methylation acquisition at a number of imprinted loci is known to generally commence later, during the growth phase of oocytes arrested at the diplotene stage of the first meiotic division (Lucifero et al. 2002). Importantly, these events are known to be immediately preceded by an increase in transcript expression for key DNMTs (La Salle et al. 2004).

\section{Epigenetic basis of DOHaD}

Existing theories provide a conceptual framework to explain how, in viviparous species, mechanisms have evolved during the course of evolution to facilitate rapid adaptations to changing ecological conditions; and that these may form the basis for the developmental origins of adult health and disease. From the preceding discussion it is apparent that extensive covalent modifications to DNA and related proteins occur from the earliest stages of mammalian development to determine lineage-specific patterns of gene expression; and so these represent the most plausible mechanisms by which environmental factors such as diet can influence development during the life course. Indeed, both the nature and extent of the modifications which occur normally during gametogenesis and early embryogenesis suggest that these may be particularly vulnerable periods during which epimutations can be induced. However, it is also apparent that our understanding of how these epigenetic processes may underpin the environmentally-induced phenotypic modifications discussed earlier is far from complete. The following discussion highlights some of the major findings of recent years with some thoughts on future directions.

\section{Inducing epigenetic modifications}

In addition to the epigenetic modifications that occur as a part of normal development, changes can also be induced by environmental factors although often the mechanisms by which these effects arise are unclear. For example, short term exposure of mammalian zygotes to nonphysiological in vitro culture environments can lead to epigenetic alterations in global DNA methylation in mice (Shi \& Haaf 2002) and genomic imprinting in sheep (Young et al. 2001). Recently, transient exposure of gestating female rats to specific endocrine disrupting compounds during the period of fetal gonadal sex determination was shown to decrease spermatogenic capacity and increase male infertility in offspring; effects associated with altered DNA methylation at several loci (Anway et al. 2005). Also, in altricial mammals, infant licking and grooming by the mother during the first week of life can reversibly modify DNA methylation and histone acetylation at the glucocorticoid receptor promoter, thereby altering glucocorticoid receptor (GR) expression (Meaney \& Szyf 2005). Dietary induced epigenetic effects have also been reported in mice following weaning. For example, synthetic diets and diets deficient in folic acid, vitamin B12, methionine and choline offered to weanlings each caused a persistent loss of imprinting of Igf2 in the kidney relative to controls (Waterland et al. 2006).

Of particular relevance to the DOHaD hypothesis are the observations that alterations to maternal diet during pregnancy and/or lactation can also lead to epigenetic modifications in DNA methylation associated with varied phenotypic outcomes. For example, viable yellow 
agouti (Avy) mice harbour a transposable element (responsible for ectopic agouti transcription) at the agouti locus, the epigenetic status of which is metastable. Recently, Waterland \& Jirtle (2003) demonstrated that dietary supplementation with the methyl donors folate, vitamin B12, choline and betaine throughout gestation and lactation can increase $\mathrm{CpG}$ methylation at this site, modifying the expression of the agouti gene which lies adjacent to the transposable element. Significantly, these authors observed that the $A^{\text {vy }}$ methylation status of tissues derived from the three germ layers of the early embryo were affected indicating that the effects are likely to have been induced during early embryo development. Subsequent studies with genistein (the major isoflavone in soy) offered to gestating female mice at physiological levels also found alterations in coat colour of heterozygous viable agouti offspring toward the mottled agouti phenotype (Dolinoy et al. 2006). Moreover, these effects, which were associated with a similar increase in methylation at the agouti locus, persisted into adulthood and reduced the incidence of obesity, a phenotype commonly associated with ectopic agouti expression. Significantly, the increase in DNA methylation at this locus occurred in the absence of any effect on either SAM or SAH (Fig. 1), indicating a dietary-induced epigenetic mechanism independent of single carbon metabolism.

Recent studies in the rat, using protein restricted diets similar to those employed in previous studies with this species (Table 1), assessed the methylation status and expression of the GR and peroxisomal proliferator-activated receptor (PPAR) genes in weanlings (Lillycrop et al. 2005). Methylation-sensitive PCR revealed a significant reduction in CpG methylation in the promoter regions of both PPARa and GR which, in each case, was associated with a significant increase in gene expression. Importantly, the inclusion of $1 \mathrm{mg} / \mathrm{kg}$ folic acid in the protein restricted diet reversed the effects of protein restriction on DNA methylation and the expression of both genes. Although epigenetic mechanisms were not determined, Jackson et al. (2002) was able to demonstrate that the non-essential amino acid glycine (which plays a key role in methionine and SAM metabolism [Fig. 1] via the actions of glycine methyltransferase [Table 3]) was able to reverse the effects of protein restriction during pregnancy on offspring blood pressure in Wistar rats. These studies serve to further demonstrate that epigenetic effects may be involved in changes of phenotype due to the macronutrient composition of the maternal diet.

\section{Transgenerational epigenetic inheritance}

The most significant observation from the study of Anway et al. (2005), cited earlier, was that both epigenetic and phenotypic effects observed in the F1 generation persisted in all subsequent generations studied (i.e. F1 through to F4) indicating that, in the absence of genetic mutations, phenotypic effects can be transmitted to successive generations via epigenetic inheritance. Clues that such inheritance patterns may exist in mammals were provided earlier when the altered phenotypes and patterns of gene expression observed in mouse nucleocytoplasmic hybrids were found to be present in their offspring (Roemer et al. 1997). There is also evidence of epigenetic transgenerational inheritance at the viable yellow agouti (Avy) locus where, in the absence of alterations to the nutritional environment, the phenotype of the offspring has been found to resemble that of the dam; indicating incomplete erasure of epigenetic modifications through the female germline (Morgan et al. 1999). Evidence of paternal as well as maternal transmission of epigenetic modifications in mice was later provided for the axin-fused (Axin ${ }^{\mathrm{Fi}}$ ) allele (involved in determining embryonic axis formation in vertebrates) which is also associated with a retrotransposon; the methylation state of this allele in mature sperm closely resembled that of somatic cells of the animal suggesting this also was not completely erased through the germline (Rakyan et al. 2003). 
The significance of these observations is that they establish the principle of transgenerational epigenetic inheritance in manmals, previously only observed in plants and fission yeast (Chong \& Whitelaw 2004). None of these examples, however, could be considered to meet the criteria of PARs described by Gluckman \& Hanson (2004) or the inter-generational effects predicted by the phenotypic inertia model of Kuzawa (2005). Nevertheless, they demonstrate that environmentally induced epigenetic modifications, which may lead to adult disease, can be transmitted to future generations through the germ line.

\section{Fulure directions}

The foregoing discussion highlights both the complexity of epigenetic mechanisms and our current lack of understanding of how they may contribute to in utero programming. It does, however, provide some guidance for future research endeavours. The evidence contained within this article indicates that both nutritional and non-nutritional factors contribute to the $\mathrm{DOHaD}$. To date, the former has relied largely on two experimental paradigms that involve either calorie or protein restriction. In contrast, ongoing collaborative investigations between the authors' laboratories are assessing the effects of deficiencies in specific micronutrients (i.e. methionine, choline, folate, vitamin B12 and B6) that are known to directly influence single carbon metabolism. The clinical significance of these nutrients is that their consumption is acknowledged to be highly variable in most Western societies and also in developing countries (e.g. Stabler \& Allen 2004). The focus in future, therefore, should be directed towards understanding the effects of specific dietary nutrients and environmental factors. Further detailed studies should recognise (i) that the epigenetic regulatory mechanisms involved in environmentally induced gene disregulation encompass complex interactions between non-transcribed RNAs and covalently altered proteins as well as DNA, and (ii) that the susceptibility of individuals to environmentally induced epimutations may have a genetic base. The significance of this latter point is that the metabolic responses which can epigenetically modify chromatin vary between individuals as a consequence of polymorphic variation in relevant enzymes. Although it will be necessary to establish such relationships in model animal species, direct studies in human cells will be of greatest value. To this end we have begun to identify key polymorphisms in enzymes directing the combined methionine/folate cycles within human embryonic stem cells, which serve as a model of the human embryo (Allegrucci et al. 2005b). Complementary studies in appropriate animal models will allow such investigations to take place at later stages of gestation and confirm their significance with respect to the onset of adult disease. They would also permit the investigation of transgenerational inheritance.

\section{Acknowledgements}

Original research is supported by a cooperative agreement from the National Institutes of Health, NICHD (U01-HD044638) awarded to Sinclair, Lea, Rees and Young, and the Biotechnology and Biological Sciences Research Council (BBS/B/06164) awarded to Young and Sinclair.

\section{References}

Allegrucci C, Thurston A, Lucas E \& Young L 2005a Epigenetics and the germline. Reproduction 129137 149.

Allegrucci $C$, Denning $C N$, Burridge $P$, Steele $W$,
Sinclair KD \& Young IE 2005b Human embryonic stem cells as a model for nutritional programming: an evaluation. Reproductive Toxicology 20353. 367. 
Anthony RV, Scheaffer AN, Wright CD \& Regnault TR 2003 Ruminant models of prenatal growth restriction. Reproduction Supplement 61 183-194.

Anway MD, Cupp AS, Uzumcu M \& Skinner MK 2005 Epigenetic transgenerational actions of endocrine disruptors and male fertility. Science 308 1466-1469.

Bannister AJ \& Kouzarides T 2005 Reversing histone methylation. Nature 436 1103-1106.

Barker DJ \& Osmond C 1988 Low birth weight and hypertension. British Medical Journal 297 134-135.

Barker DJ, Winter PD, Osmond C, Margetts B \& Simmonds SJ 1989 Weight in infancy and death from ischaemic heart disease. The Lancet $2577-580$.

Barker DJ 1995 The Wellcome Foundation Lecture, 1994. The fetal origins of adult disease. Proceedings of the Biological Sciences $262 \quad 37-43$.

Bateson P 2001 Fetal experience and good adult design. International lournal of Epidemiology 30928 . 934.

Beaujean N, Hartshorne G, Cavilla J, Taylor J, Gardner J, Wilmut I, Meehan R \& Young L 2004a Nonconservation of mammalian preimplantation methylation dynamics. Current Biology 14 R266-R267.

Beaujean N, Taylor IE, McGarry M, Gardner JO, Wilmut I, Loi P, Ptak G, Galli C, Lazzari G, Bird A, Young LE \& Meehan RR $2004 b$ The effecl of interspecific oocytes on demethylation of sperm DNA. Proceedings of the National Academy of Sciences U.5.A $1017636-7640$.

Bloomfield FH, Oliver $\mathrm{MH}$, Giannoulias CD, Gluckman PD, Harding JE \& Challis JR 2003 Brief undernutrition in late-gestation sheep programs the hypothalamic-pituitary-adrenal axis in adult offspring. Endocrinology 144 2933-2940.

Caiafa P \& Zampiera M 2005 DNA methylation and chromatin struclure: the puzzling CPG islands. Journal of Cellular Biochemistry 94 257-265.

Chong S \& Whitelaw E 2004 Epigenetic germline inheritance. Current Opinions in Genetics and Development 14 692-696.

Chowdhury D, Keogh MC, Ishii H, Peterson CL, Buratowski S \& Lieberman J 2005 gamma-H2AX dephosphorylation by protein phosphalase $2 \mathrm{~A}$ facililates DNA double-strand break repair. Molecular Cell 20 801-809.

Cresswell IL, Egger P, Fall CHD, Osmond C, Fraser RB \& Barker DIP 1997 is the age of menopause determined in-utero? Early Human Development 49 143148

Danilovich N \& Ram Sairam M 2006 Recent female mouse models displaying advanced reproductive aging, Experimental Gerontology 41 117-122.

Davis L, Roullet JB, Thornburg KL, Shokry M, Hohimer AR \& Giraud GD 2002 Journal of Physiology 547 53-9.

de Bree A, Verschuren WM, Bjorke-Monsen AL, van der Put NM, Heil SG, Trijbels FI \& Blom HI 2003 Effect of the methylenetetrabydrofolate reductase $677 \mathrm{C} \rightarrow \mathrm{T}$ mutation on the relations among folate intake and plasma folate and homocysteine concen- trations in a general population sample. American Journal Clinical Nutrition 77 687-693.

Detich N, Hamm S, Just G, Knox JD \& Szyf M 2003 The methyl donor S-Adenosylmethionine inhibits active demethylation of DNA: a candidate novel mechanism for the pharmacological effects of 5 Adenosylmethionine. lournal Biological Chemistry $27820812-20820$.

Doblhammer G \& Vaupel IW 2001 Lifespan depends on month of birth. Proceedings National Acrdemy Sciences U.S.A 98 2934-2939.

Dolinoy DC, Weidman JR, Waterland RA \& Jirtle RL 2006 Maternal genistein allers coat color and protects Avy mouse offspring from obesity by modifying the fetal epigenome. Environmental Health Perspectiv $114567-572$.

Edwards LJ \& McMillen IC 2002 Periconceptional nutrition programs development of the cardiovascular system in the fetal sheep. American Journal Physiology, Regulation, Integration and Comparative Physiology 283 R669-R679.

Fang J, Chen T, Chadwick B, Li E \& Zhang Y 2004 Ring $1 \mathrm{~b}$-mediated $\mathrm{H} 2 \mathrm{~A}$ ubiquitination associates with inactive $\mathrm{X}$ chromosomes and is involved in initiation of X inactivation. Journal Biological Chemistry 279 $52812-52815$

Fischle W, Wang Y \& Allis CD 2003 Histone and chromatin cross-lalk. Current Opinion Cell Biology 15 172-183.

Fischle W, Tseng BS, Dormann HL, Ueberheide BM, Garcia BA, Shabanowitz J, Hunt DF, Funabiki H \& Allis CD 2005 Regulation of HP1-chromatin binding by histone $\mathrm{H}_{3}$ methylation and phosphorylation. Nature 438 1116-1122.

Francis J, Chakrabarti SK, Garmey JC \& Mirmira RG 2005 Pdx-1 links histone H3-Lys-4 methylation to RNA polymerase II elongation during activation of insulin Iranscription. Journal Biological Chemistry 280 36244-36253.

Freitas RA Jr. 1999, Cytometries In: Nanomedicine, Vol. I: Basic Capabilities, Landes Biosciencé, Georgetown, TX, USA.

Frisch RE 1994 The right weight: body fat, menarche and fertility. Proceedings of the Nutrition Society 53 113-129.

Fuks F 2005 DNA methylation and histone modifications: teaming up to silence genes. Current Opinion Genetics andDevelopment 15 490-495.

Gardner DS, Pearce S, Dandrea J, Walker R, Ramsay MM, Stephenson T \& Symonds ME 2004 Peri-implantation undernutrition programs blunted angiolensin II evoked baroreflex responses in young adult sheep. Hypertension 43 1290-1296.

Gilbert IS, Lang AL, Grant AR \& Nijland MJ 2005 Maternal nutrient restriction in sheep: hyperlension and decreased nephron number in offspring at 9 months of age. Journal of Physiology 565 137-147.

Giussani DA, Forhead AJ, Gardner DS, Fletcher AJ, Allen WR \& Fowden AL 2003 Posinatal cardiovascular funclion after manipulation of felal growth by 
embryo transfer in the horse fournal of Physiology $54767-76$.

Gluckman PD \& Hanson MA 2004 The developmental origins of the metabolic syndrome. Trends in Endocrinology and Metabolism 15 183-187.

Golding MC \& Westhusin ME 2003 Analysis of DNA (cylosine 5) methyltransferase mRNA sequence and expression in bovine preimplantation embryos, fetal and adult tissues. Gene Expression Pattems 3551 . 558.

Goll MG \& Bestor TH 2005 Eukaryotic cytosine methyltransferases. Annual Reviews in Biochemistry 74 481-514.

Hajkova P, Erhardt S, Lane N, Haaf T, El-Maarri O, Reik W, Walter J \& Surani MA 2002 Epigenetic reprogramming in mouse primordial germ cells. Mechanisms of Development 117 15-23.

Hales CN \& Barker DJ 1992 Type 2 (non-insulin-dependent) diabeles mellitus: the thrifty phenolype hypothesis. Diabetologia 35 595-601.

Hardy R \& Kuh D 2002 Does early growth influence timing of the menopause? Evidence from a British birth cohort. Human Reproduction 17 2474-2479.

Heininger K 2002 Aging is a deprivation syndrome driven by a germ-soma conflicl. Ageing Research Reviews 1 481-536.

Holliday R 2005 Ageing and the extinction of large animals. Biogerontology 6 151-156.

Huxley R, Neil A \& Collins R 2002 Unravelling the fetal origins hypothesis: is there really an inverse association between birthweight and subsequent blood pressure? Lancet $360659-665$.

Ibanez L, Potau N, Ferrer A, Rodriguez-Hierro F, Marcos MV \& De ZF 2002 Anovulation in eumenorrheic, nonobese adolescent girls born small for gestational age: insulin sensitization induces ovulation, increases lean body mass, and reduces abdominal fat excess, dyslipidemia, and subclinical hyperandrogenism. Journal of Clinical Endocrinology and Metabolism 87 5702-5705.

Jablonka E 1994 Inheritance syslems and the evolution of new levels of individuality. Journal of Theological Biology 170 301-309.

Jackson AA, Dunn RL, Marchand MC \& Langley-Evans SC 2002 Increased systolic blood pressure in rats induced by a maternal low-protein diet is reversed by dietary supplementafion with glycine. Clinical Science (London) 103 633-639.

Khan IY, Taylor PD, Dekou V, Seed PT, Lakasing L, Graham D, Dominiczak AF, Hanson MA \& Poston L 2003 Gender-linked hypertension in offspring of lard-fed pregnanl rats. Hypertension 41 168-75.

Kirkwood TB 2005 Understanding the odd science of aging, Cell 120 437-447.

Klenova EM, Morse HC, III, Ohlsson R \& Lobanenkov VV 2002 The novel BORIS + CTCF gene family is uniquely involved in the epigenetics of normal biology and cancer. Seminars in Cancer Biology 12 399-414.

Klose RJ \& Bird AP 2006 Genomic DNA methylation: the mark and its mediators. Trends in Biochemical Science 31 89-97.

Kouzarides T 1999 Histone acetylases and deacetylases in cell proliferation. Current Opinion in Genetics and Development 9 40-48.

Kremenskoy M, Kremenska Y, Ohgane J, Hattori N, Tanaka S, Hashizume K \& Shiota K 2003 Biochemisty and Biophysics Research Communications $311884-890$.

Kuzawa CW 2005 Fetal origins of developmental plasticity: Are fetal cues reliable predictors of future nutritional environments? American fournal of $\mathrm{Hu}$ man Biology 17 5-21.

Kwong WY, Wild AE, Roberts P, Willis AC \& Fleming TP 2000 Maternal undernutrition during the preimplantation period of rat development causes blastocyst abnormalities and programming of posinatal hypertension. Development 127 4195-4202.

La Salle S, Mertineit C, Taketo T, Moens PB, Bestor TH \& Trasler IM 2004 Windows for sex-specific methylation marked by DNA methyltransferase expression profiles in mouse germ cells. Developmental Biology $268403-415$.

Lander ES, Linton LM, Birren B, et al. 2001. Initial sequencing and analysis of the human genome. Nature $409860-921$.

Langley-Evans SC, Welham SJ, Sherman RC \& Jackson AA 1996 Weanling rats exposed to maternal low-protein diets during discrete periods of gestation exhibit differing severity of hypertension. Climical Science (London) 91 607-615.

Langley-Evans SC 2006 Developmental programming of health and disease: Proceedings of the Nutrition Society 65 97-105.

Lee DY, Teyssier C, Strahl BD \& Stallcup MR 2005 Role of protein methylation in regulation of transcription. Endocrine Reviews 26 147-70.

Leroi AM, Bartke A, De BG, Franceschi C, Gartner A, Gonos ES, Fedei ME, Kivisild T, Lee S, Kartaf-Ozer N, Schumacher M, Sikora E, Slagboom E, Tatar M, Yashin Al, Vijg J \& Zwaan B 2005 What evidence is there for the existence of individual genes with antagonistic pleiotropic effects? Mechanisms of Ageing and Development 126 421-429.

Lillycrop KA, Phillips ES, Jackson AA, Hanson MA \& Burdge GC 2005 Dietary protein restriction of pregnant rals induces and folic acid supplementalion prevents epigenelic modification of hepatic gene expression in the offspring. Journal of Nutrition 135 1382-1386.

Lobley GE, Connell A \& Revell D 1996 The imporlance of Iransmethylation reactions to methionine metabolism in sheep: effects of supplementation with creatine and choline. British Journal of Nutrition 75 47-56.

Louey S, Cock ML, Stevenson KM \& Harding R 2000 Placental insufficiency and felal growth restriction lead to postnatal hypotension and altered postnatal growth in sheep. Pediatric Research $\mathbf{4 8}$ 808-814.

Lucas A, Fewtrell MS \& Cole TJ 1999 Felal origins of 
adult disease-the hypothesis revisited. British Medical Journal 319 245-249.

Lucifero D, Mertineit C, Clarke HJ, Bestor TH \& Trasler JM 2002 Melhylation dynamics of imprinted genes in mouse germ cells. Genomics 79 530-538.

Lumey LH 1992 Decreased birlhweights in infants after maternal in utero exposure to the Dutch famine of 1944-1945. Paediatrics Perinatology and Epidemiology 6 240-253.

Lumey LH 1998 Reproductive outcomes in women prenatally exposed to undernulrition: a review of findings from the Dutch famine birth cohort. Proceedings of the Nutrition Society 57 129-135.

Maltin CA, Delday MI, Sinclair KD, Steven J \& Sneddon AA 2001 Impacl of manipulations of myogenesis in utero on the performance of adult skelelal muscle. Reproduction 122 359-374.

Matsui Y \& Okamura D 2005 Mechanisms of germ-cell specification in mouse embryos. BioEssays 27 136143.

Maxfield EK, Sinclair KD, Dunne LD, Broadbent PJ, Robinson IJ, Stewart E, Kyle DG \& Maltin CA 1998 Temporary exposure of ovine embryos to an advanced uterine environment does not affect fetal weight but alters fetal muscle development. Biology of Reproduction 59 321-325.

McGraw S, Robert C, Massicotte L \& Sirard MA 2003 Quantification of histone acetyltransferase and histone deacetylase transcripts during early bovine embryo development. Biology of Reproduction 68 383-389.

McMillen IC \& Robinson IS 2005 Developmental origins of the metabolic syndrome: prediction, plasticity, and programming. Physiological Reviews $\mathbf{8 5}$ $571-633$.

Meaney MJ \& Szyf M 2005 Environmental programming of stress responses through DNA methylation: life at the interface between a dynamic environment and a fixed genome. Dialogues in Clinical Neuroscience 7 103-123.

Moore T \& Reik W 1996 Genelic conflict in early development: parental imprinting in normal and abnormal growth. Reviews of Reproduction 1 73-77.

Morgan HD, Sutherland HG, Martin DI \& Whitelaw E 1999 Epigenetic inheritance at the agouti locus in the mouse. Nature Cenetics 23 314-318.

Oswald I, Engemann S, Lane N, Mayer W, Olek A, Fundele R, Dean W, Reik W \& Walter J 2000 ACtive demethylation of the paternal genome in the mouse zygote. Current Biology 10 475-478.

Owens IA, Falconer J \& Robinson JS 1989 Glucose melabolism in pregnant sheep when placental growth is restricted. American Journal of Physiology 257 R350-R357.

Painter RC, Roseboom TJ \& Bleker OP 2005 Prenatal exposure to the Dutch famine and disease in later life: an overview. Reproductive Toxicology $20345-$ 352.

Phelan JP \& Rose MR 2005 Why dietary restriction substantially increases longevily in animal models but won't in humans. Ageing Research Reviews 4
339-350.

Preuss U, Landsberg G \& Scheidtmann KH 2003 Novel mitosis-specific phosphorylation of histone $\mathrm{H} 3$ at Thr11 mediated by DIk/ZIP kinase. Nucleic Acids Research 31 878-885.

Rae MT, Kyle CE, Miller DW, Hammond A], Brooks AN \& Rhind SM 2002 The effects of undernutrition, in utero, on reproductive function in adult male and female sheep. Animal Reproduction Science 72 6371.

Rakyan VK, Chong S, Champ ME, Cuthbert PC, Morgan HD, Luu KV \& Whitelaw E 2003 Transgenerational inheritance of epigenetic stales at the murine $A x i n(F u)$ allele occurs after maternal and paternal transmission. Proceedings National Acactemy of Science U,S.A 100 2538-2543.

Ravelli AC, van der Meulen JH, Michels RP, Osmond C, Barker DJ, Hales CN \& Bleker OP 1998 Glucose tolerance in adults after prenatal exposure to famine. The Lancet 351 173-177.

Rhind SM, Elston DA, Jones JR, Rees ME, McMillen SR \& Gunn RG 1998 Effects of restriclion of growth and development of Brecon Cheviot ewe lambs on subsequent lifetime rèproductive performance Small Ruminant Research 30 121-126

Roemer I, Reik W, Dean W \& Klose J 1997 Epigenetic inheritance in the mouse. Current Biology 7277 . 280.

Roof KA, Hopkins WD, lzard MK, Hook M \& Schapiro S) 2005 Maternal age, parity, and reproductive outcome in captive chimpanzees (Pan troglodyles). American lournal of Primatology 67 199-207.

Rousseaux S, Caron C, Govin J, Lestrat C, Faure AK \& Khochbin S 2005 Establishment of male-specific epigenetic information. Gene $\mathbf{3 4 5}$ 139-153.

Rupp RA, Singhal N \& Veenstra GJ 2002 When the embryonic genome flexes its muscles. European Journal of Biochemistry 269 2294-2299.

Santos F, Hendrich B, Reik W \& Dean W 2002 Dynamic reprogramming of DNA methylation in the early mouse embryo. Developmental Biology 241 172-182.

Santos F, Peters AH, Otte AP, Reik W \& Dean W 2005 Dynamic chromalin modifications characterise the first cell cycle in mouse embryos. Developmental Biology 280 225-236.

Schultz RM 2002 The molecular foundations of the maternal to zygotic transition in the preimplantation embryo. Human Reproduction Update 8 323-331.

SeckI JR 2001 Glucocorticoid programming of the fetus; adult phenotypes and molecular mechanisms. Molecular and Cellular Endocrinology 185 61-71.

Sharp L \& Little I 2004 Polymorphisms in genes involved in folate metabolism and colorectal neoplasia: a HuGE review. American Journal of Epidemiology 159 423-443.

Shi W \& Haaf T 2002. Aberrant methylation patterns at the Iwo-cell slage as an indicator of early developmental failure. Molecular Reprodion and Developinent $63329-334$.

Shi Y, Lan F, Matson C, Mulligan P, Whetstine JR, 
Cole PA, Casero RA \& Shi Y 2004 Histone demethylation mediated by the nuclear amine oxidase homolog LSD1. Cell 119941 -953.

Shiota K, Kogo Y, Ohgane J, Imamura T, Urano A, Nishino K, Tanaka S \& Hattori N 2002 Epigenelic marks by DNA methylation specific to stem, germ and somatic cells in mice. Genes and Cells 7961 . 969.

Shiio Y \& Eisenman RN 2003 Histone sumoylation is associated with transcriptional repression Proceedings of the National Academy of Sciences U S A 100 $13225-13330$.

Singhal A \& Lucas A 2004 Early origins of cardiovascular disease: is there a unifying hypothesis? The Lancet 363 1642-1645.

Snoswell AM \& Xue GP 1987 Methyl group metabolism in sheep. Comparative Biochemistry and Physiology B $\mathbf{8 8} 383-394$.

Snowden AW, Gregory PD, Case CC \& Pabo CO 2002 Gene-specific targeting of $\mathrm{H} 3 \mathrm{~K} 9$ methylation is sur. ficient for initiating repression in vivo. Current Biology 12 2159-2166.

Sjöblom C, Roberts CT, Wikland M \& Robertson SA 2005 Granulocyte-macrophage colony-stimulating factor alleviates adverse consequences of embryo culture on fetal growth trajectory and placental morphogenesis. Endocrinology $1462142-2153$.

Stabler SP \& Allen RH 2004 Vitamin B 12 deficiency as a worldwide problem. Annual Reviews of Nutrition 24 299-326.

Stanner SA, Bulmer K, Andres C, Lantseva OE, Borodina V, Poteen VV \& Yudkin JS 1997 Does malnutrition in utero determine diabetes and coronary heart disease in adulthood? Results from the Leningrad siege study, a cross sectional study. British Medical Journal 315 1342-1348.

Stewart RJC, Sheppard H, Preece R \& Waterlow IC 1980 The effect of rehabilitation at different stages of development of rats marginally malnourished for ten to twelve generations. British fournal Nutrition $43403-412$
Stipanuk MH 2004 Sulfur amino acid melabolism: Pathways for production and removal of homocysteine and cysteine. Annual Reviews of Nutrition 24539 . 577

Vairapandi M 2004 Characterization of DNA demethylation in normal and cancerous cell lines and the regulatory role of cell cycle proleins in human DNA demethylase activity. Journal Cellular Biochemistry $91572-583$.

Vassena R, Dee SR \& Latham KE 2005 Species-dependent expression patterns of DNA methyltransferase genes in mammalian oocytes and preimplantation embryos. Molecular Reproduction and Development 72 430-436.

Wang Y, Wysocka J, Sayegh J, Lee YH, Perlin JR, Leonelli L, Sonbuchner IS, McDonald CH, Cook RG, Dou Y, Roeder RG, Clarke S, Stallcup MR, Allis CD \& Coonrod SA 2004 Human PAD4 regulates histone arginine methylation levels via demethylimination. Science 306 279-283.

Waterland RA \& Jirtle RL 2003 Transposable elements: targets for early nutritional effects on epigenetic gene regulation. Molecular and Cellular Biology 235293 . 5300.

Waterland RA, Lin J-L, Smith CA \& Jirtle RL 2006 Postweaning diel affects genomic imprinting at the insulin-like growth factor 2 (Ig/2) locus. Human Molecular Genetics 15 705-716.

Yamagoe S, Kanno T, Kanno Y, Sasaki S, Siegel RM, Lenardo MJ, Humphrey G, Wang Y, Nakatani V, Howard BH \& Ozato K 2003 Interaction of histone acetylases and deacetylases in vivo. Molecular and Cellular Biology 23 1025-1033.

Young LE, Fernandes K, McEvoy TG, Butterwith SC, Gutierrez CG, Carolan C, Broadbent PJ, Robinson J), Wilmut I \& Sinclair KD 2001 Epigenetic change in IGF2R is associated with fetal overgrowth after sheep embryo culture. Nature Genetics 27 153-154.

Young LE \& Beaujean N 2004 DNA methylation in the preimplantation embryo: the differing stories of the mouse and sheep. Anumal Reproduction Science $\mathbf{8 2}$ 83 61-78. 